University of Nebraska - Lincoln

DigitalCommons@University of Nebraska - Lincoln

Faculty Publications: Department of Teaching, Department of Teaching, Learning and Teacher Learning and Teacher Education

6-2013

\title{
The Roma and Wall Street/CEOs: Linguistic construction of identity in U.S. and Canadian crime reports
}

Theresa Catalano

University of Nebraska-Lincoln, tcatalano2@unl.edu

Follow this and additional works at: https://digitalcommons.unl.edu/teachlearnfacpub

Catalano, Theresa, "The Roma and Wall Street/CEOs: Linguistic construction of identity in U.S. and Canadian crime reports" (2013). Faculty Publications: Department of Teaching, Learning and Teacher Education. 133.

https://digitalcommons.unl.edu/teachlearnfacpub/133

This Article is brought to you for free and open access by the Department of Teaching, Learning and Teacher Education at DigitalCommons@University of Nebraska - Lincoln. It has been accepted for inclusion in Faculty Publications: Department of Teaching, Learning and Teacher Education by an authorized administrator of DigitalCommons@University of Nebraska - Lincoln. 


\title{
The Roma and Wall Street/CEOs: Linguistic construction of identity in U.S. and Canadian crime reports
}

\author{
Theresa Catalano \\ Department of Teaching, Learning and Teacher Education, University of Nebraska-Lincoln, Lincoln, \\ Henzlik 118, NE 68588, Nebraska, USA; email tcatalano2@unl.edu
}

\begin{abstract}
Discriminatory practices against Roma (also known as Romanies) occur on a daily basis in many countries around the world through media discourse. This paper investigates the representation of Romanies in U.S. and Canadian online newspaper crime reports and compares this representation to Wall Street/CEOs in crime reports demonstrating how identity of both groups is constructed through a variety of linguistic and non-linguistic strategies. Drawing on Mayr and Machin's (2012) critical linguistic analysis of the language of crime, this multimodal study incorporates a variety of tools such as Critical Discourse Analysis and Cognitive Linguistics in order to dig below the surface to reveal ideological frames. Results illustrate the denaturalization (and negative representation) of Romanies and contrasting naturalization of CEOs and point to a growing need for consciousness-raising through critical linguistic analysis such as this in order to continue to fight for social change and a more just system for the Roma.
\end{abstract}

Keywords: Roma, crime reports, Wall Street/CEOs, discourse analysis

\section{Introduction}

Našti garaves muca ande gono, lake vundžja ka-sitjaren-pe

"You can't hide a cat in a sack; its claws will show themselves (through it)"

(a Romani proverb taken from Hancock, 2002, p. 145)

Discriminatory practices against Roma (also known as Romanies) occur on a daily basis in many countries around the world. One way these practices occur is through media discourse, which influences the public's perception of a group and can lead to the creation of unjust policies and laws as well as hate crimes. In Europe, (e.g., Italy) much media coverage of Roma has referred to this ethnic group as the "Roma problem" and has highlighted and forefronted Romani people and their role in criminal activities placing criminal cases with Romani defendants (Read: accused, not convicted!) in high profile places in media discourse resulting in the scapegoating of Romanies and the criminalization of an entire ethnic group (see Catalano, 2011b).

While much scholarly focus on the Roma has been on policies, discrimination, crime and media discourse occurring in Europe, little attention has been paid to media discourse and discrimination of Romanies in the United States and Canada. In the past, the media has contributed greatly to discrimination against contemporary Romanies in America. For de- 
tailed examples of negative (and often defamatory) stereotypes of Romanies in newspapers, magazines, comics, books and films, see Hancock, 1987. Sadly, since 1987 there has not been much improvement in how Romanies are represented in the US media. With populations estimated at one million in the United States and 80,0oo in Canada (Kates \& Gergely, 2011; Lee, 1998), Romanies have traditionally faced challenges in both countries, but have generally managed to keep a low profile. Because in the past, U.S. and Canadian Roma settling in these new countries hailed from a variety of countries and spoke different languages upon arrival, they generally didn't settle as one, but formed "pockets based on language, nationality, or some other identifier" which may have caused identity issues, but has helped them to blend into society (Webley, 2010). Thus, because they have been able to blend into society and live among others (unlike in many European countries where they are not only socially marginalized but also physically marginalized by being forced to live in camps), Romanies in the U.S. and Canada have faired better than in most other countries, but have still experienced bias in media discourse about them as well as overt discrimination. According to noted Romani scholar (and head of the Romani Archives and Documentation Center at the University of Texas-Austin) Ian Hancock, "The media can get away with saying things about Roma that they wouldn't dare say about other minority populations" (Kates \& Gergely, 2011). The fact that overt racism against Roma is still socially acceptable in the United States and Canada could be partially due to a general lack of education about Roma, in particular, many people are not aware that "Gypsy" refers to an ethnic group and not a way of life. Indeed, much of the public's knowledge about Romanies comes from stereotypes from Hollywood (such as reality shows like "American Gypsies"), literature, music and other media. "They know about Gypsy, but not as a real ethnic group, real people. They see it more like a Halloween costume, a role that you play once a year" (Ibid). These stereotypes about Romanies have been kept alive by the media and in the words of Ian Hancock, "It is the media that needs to lay them to rest" (1994).

Canada has experienced various periods of increased Roma immigration such as when many Roma refugees came from the Czech Republic in 1997. Because of the large communities of Roma arriving in Canada the Roma Community Centre (RCC) was opened in Toronto the same year, and has been very active serving the needs of Roma refugees from many countries and aiding Romani people in integrating into Canadian society. In the last few years, many new Romanies have been arriving from Hungary (4442 in 2011 alone), and despite the efforts of the RCC, patterns of media discourse about Roma and criminality appear to be reemerging in Canadian media (see Elliot, 2012; Selley, 2012; Szandelszky, 2012).

Consequently, it is crucial that consciousness-raising occurs now as to how Roma are being portrayed in the media and how this relates to the social cognitions that the public has formed and will continue to form and reinforce if we do not discontinue this type of discourse. At the same time, it is important to heed the call of Romani scholar and ethno-musicologist Petra Gelbart to not only study Romani behavior (and in this case, how Roma are portrayed in crime reports) but to look at the wider society, concentrating not on how Roma differ but reporting on "common ground and how human values and personality distributions, good, problematic and foolish, are fundamentally the same across ethnic groups" (2011). In this case, it is useful to compare how other groups, particularly groups yielding more power in society, are viewed in the same genre of media discourse in order to understand how Roma are represented and how this differs from other groups in similar situations.

The present paper aims to do just that, and will examine in detail 35 articles that report crimes (allegedly) committed by Roma (in the U.S. and Canada) and Wall Street executives/ CEOs in the United States in online newspapers from the years 2004-2012. Beginning with 
an introduction to Mayr and Machin's (2012) approach to the study of language and crime, the author will lay out the theoretical framework and demonstrate how a combination of Critical Discourse Analysis and Cognitive Linguistics will be employed in order to break down the texts and explicate how Roma and CEO identity is constructed and how this affects public perception. After the methodology is introduced, results will be presented in the form of major themes and patterns found in crime reports featuring both Romanies and CEOs, including the representation of family and family values, examples of "Othering" (or the opposite), non-verbal representations, transitivity and the presence (or absence of) crime news frames. Finally, the paper will conclude with a summary of findings, the major contributions of the paper and future recommendations.

\section{Background}

In the past, the relationship between crime and media has been extensively studied in fields such as criminology, sociology, psychology and media studies, but there has been little study of the mediatized language of crime (Mayr \& Machin, 2012, p. 1). Cultural criminologists (associated with works such as Ferrell, Hayward, \& Young, 2008; Hayward \& Presdee, 2010; Lyng, 1990; Presdee, 1994, 2000) have emphasized the social/cultural construction of crime and crime control (Ibid, p. 5). They have also focused largely on the media's role in this process while recognizing that characteristics of late modernity such as a profound sense of insecurity and disorientation and a fear of crime and criminals that exists in discourses as well as processes outside them (Fairclough, 1999). Discourses refers to the broader ideas communicated by a text (Fairclough, 2000; van Dijk, 1993; Wodak, 2001) and in the sense expressed by Foucault, models of the world (1981). Moreover, Foucault refers to the term discourse as a way of constructing the topic, which controls the way a topic can be talked about (Hall, 1992. p. 291). For example, in the United Kingdom "current media discourses about imprisonment promote a populist and highly punitive penal policy, which sidelines debate about alternatives to prison" (Mayr \& Machin, 2012, p. 8). Thus, fueled by the media, these characteristics of late modernity (such as the fear of crime and quest for security) have greatly influenced the language and discourse. Since media criminological and sociological analyses of these issues do not specifically address discourse, this is where Critical Discourse Analysis (CDA) and Cognitive Linguistics (CL) have an important contribution to make (Ibid, p. 6).

CDA is a scholarly perspective on the study of language that "critically analyses discourse - that is to say language in use-as a means of addressing social change" (Scollon, 2001, p. 140). Historically, CDA has been heavily influenced by critical theorists such as Marx, the Frankfurt School, and Habermas (Agger, 1991; Tyson, 2006; van Dijk, 2001) and its origins can be identified in the convergence of three settings: academic, historical, and ideological (Guerrero, 2009). In CDA analysis one can

"find a wide variety of theories ranging from microsociological perspectives (Ron Scollon) to theories on society and power in Michel Foucault's tradition (Siegfried Jäger, Norman Fairclough, RuthWodak) theories of social cognition (Teun van Dijk) and grammar, as well as individual concepts that are borrowed from larger theoretical traditions" (Meyer, 2001, p. 18).

Because CDA analysts explicitly define and defend their own sociopolitical position, it is in essence discourse analysis "with an attitude" (van Dijk, 2001, p. 96). CDA focuses on social problems and in particular, the role of discourse in the production and reproduction of power 
abuse or domination and specifically considers institutional, political, gender and media discourses which demonstrate relations of struggle and conflict. CDA requires integrated analysis at all levels and dimensions and must be multidisciplinary in nature and often encompasses the areas of social psychology, history, ethnography, anthropology, sociology, and many other disciplines. CDA is especially apt at demonstrating how the use and abuse of social power and social inequality is produced, reproduced and maintained through language (Mayr \& Machin, 2012, p. 8). In this frame, language is seen not as transparent or representational, but as "constructing versions of social reality that then [...] enter the discursive economy to be circulated, exchanged, stifled, marginalized or perhaps come to dominate over other possible accounts" (Wetherell, 2003, p. 16). In the case of the present paper, van Dijk's social cognition model of CDA is particularly useful in understanding how the repeated representation of the Roma in crime reports leads to negative stereotypes (2001). Social cognitions can be understood as the socially shared representations of societal groups and relations, as well as mental processes such as interpretation, thinking and arguing, making inferences and learning that form a core element of the individual's social identity (Wagner, 199, p. 132, as cited in Meyer, 2001; van Dijk, 1993b). The exercise of power involves the influence of knowledge, beliefs, values, plans, attitudes, ideologies, norms and values, all part of social cognition. Therefore, control of the public mind is accomplished through linking the discourse to social cognitions. Social cognitions explain the production as well as the understanding of discourse. van Dijk also explains how discursive units larger than the sentence are linked to the generation of prejudice. This is done by incorporating the idea of context models. Context models are mental representations that control much of discourse production and understanding such as genre, topic choice, local meanings and coherence, along with speech acts, rhetoric, and style (Wodak \& Meyer, 2001, p. 109). Context models allow us to explain what is relevant for the participants in a social situation. Groups in power affect discourse through the social representations shared by groups and these mental models. Thus, when looking at Roma crime reports, CDA can help us to bridge the gap between the micro (language use, discourse, verbal interaction, and communication) and macrolevel (power, dominance, and inequality between social groups) of society, and is thus particularly useful.

Visual elements in texts can no longer be ignored as they have become ubiquitous in media discourse, and visual communication is often used to "communicate things that may be more difficult to express through language, since images do not tend to have such fixed meaning- or at least the producer can always claim that meaning is more suggestive and open" (Mayr \& Machin, 2012, p. 29). CDA (when combined with visual semiotic resources) is helpful in looking at visual elements in texts, and breaking them down to understand the way that individual elements and features can communicate implicit or indirect meanings. In this manner, van Leeuwen's (2008) and Kress \& van Leeuwen's (1996/2007) models of analysis of image will be adopted to show how image can be changed and strategically manipulated to aid the viewer in mapping out the social world. Important elements of visual analysis adopted for this analysis include the key elements of distance, angle and gaze, which are always present when social actors are represented in visual communication. According to van Leeuwen, in pictures, distance becomes symbolic and indicates the closeness of our relationships (2008, p. 138). Thus if a person is shown in a "close-up" shot, they are shown as if "one of us", whereas the opposite is implied in a "long shot." Vertical camera angle on the other hand, is related to power differences, thus looking down on someone (in a downward camera angle) is to "exert imaginary symbolic power over a person", whereas looking up at someone demonstrates social elevation and authority of the social actor (Ibid, p. 139). In contrast, the horizontal angle denotes symbolic involvement or de- 
tachment. In addition to describing distance, angle and gaze, van Leeuwen's approach to visual analysis is particularly potent in the analysis of how people are depicted by looking at the roles social actors are seen as playing in the images (i.e., positive o negative), how they are categorized (using cultural o biological characteristics) and whether they are seen as individuals or groups (2008).

Cognitive Linguistics (CL) is another powerful approach to the study of language that focuses on conceptual systems, human cognition and meaning construction (Hart, 2011, p. 71). CL fits comfortably within CDA, and like CDA, CL maintains that "language always communicates a particular perspective, (Hart, 2010, p. 26). However, while CDA shows how ideology is encoded in text at the description stage, the cognitive approach to discourse employed in CL accounts for meaning construction at both the description and interpretation stages (Ibid, p. 23). Since "communication is based on the same conceptual system that we use in thinking and acting, language is an important source of evidence of what that system is like" (Lakoff \& Johnson, 1980, p. 3). CL therefore offers theoretical and analytical opportunities which enable the critical assessment of ideologies (Dirven, Polzenhagen \& Wolf, 2007, p. 1236) and is beneficial in helping us to understand how media crime reports of Romanies and CEOs affect public perception and lead to positive or negative consequences for both groups.

Three elements of CL are particularly useful in this analysis and will be implemented for this study. They are frames, metaphor and metonymy. According to George Lakoff, "Frames are the mental structures that allow human beings to understand reality-and sometimes to create what we take to be reality" (2006, p. 59). A salient example of the use of frames can be found in the way people talk about immigration using words such as "illegal aliens" "illegals" and "illegal immigration." With these lexical items, immigrants are being viewed in the frame of crime and criminality, in which case, no matter what the facts says about the benefits of immigrants to society, it will be difficult to win the argument when immigrants are framed in this way. The framing of concepts can be accomplished through the use of metaphor as well as metonymy. Metaphor can be defined as "a comparison that shows how two things that are not alike in most ways are similar in one important way" (Lakoff \& Johnson, 1980, p. 5). Thus metaphor is understanding and experiencing one thing in terms of another (ibid). In Santa Ana's well-known study of media discourse about migrant workers in the L.A. Times, lexical items such as "hungering" "lured" and "hunt out" were used to denaturalize and dehumanize 1 immigrants in mainstream media creating the metaphor of IMMIGRANTS ARE ANIMALS which allowed people to justify inhumane treatment of these workers (1999, p. 200-201). Metonymy on the other hand, is when one element in a frame stands for an another element in the same frame that it is closely related to or associated with which allows for mental access to it (Kövesces, 2006, p. 112). A clear example of a metonymy (besides the already mentioned illegals) used for purposes of representing a group positively is the term job creator. When we call a wealthy person a job creator, we are mapping one specific characteristic of a wealthy person (the fact that they invest the money they have into creating jobs) onto the concept of "wealthy person." This strategic use of job creator hides the other negative qualities (or at least, less needed in society) and foregrounds the positive effects that wealthy people might have on society. According to Lakoff, the repetition of the same words such as job creator is effective because these "surface frames" latch on and activate "deep frames", which (by repetition) strengthen neural connections in listeners between wealthy person and job creator which then create the impression that wealthy people generally do good for society (2006, p. 95). In this manner we may be less apt to vote for policies (such as raising taxes) that many wealthy people are against. 
In summary, CDA and CL are essential tools in this analysis because they aid in breaking down the text through grammatical, lexical and visual elements, and allow us to identify frames, metaphors and metonymies in the crime reports so we can better understand their effects on the public's social cognitions of both groups. We will now turn our attention to the process of data collection and analysis.

\section{Method}

The 35 articles selected for analysis in this paper come from online newspapers in the United States and Canada from the years 2004-2012. The 23 articles referring to crimes reportedly committed by Roma were found mostly in local online newspapers such as the Palm Beach Post and Fox Chicago News, and in papers with large readership such as the NY Daily News and NY Post. Articles from Canada included those from www.upi.com and The Toronto Sun. An initial search was carried out through www.google.com as well as the newspaper search section by searching the terms Roma/Rrom/Rromani/Romani/Romany. When no articles reporting crimes were found, a search was conducted with the terms Gypsy/gypsy/ Gypsies/gypsies/Gipsies combined with the words arrested, charged, convicted and accused. Twenty-three articles were found to fit the following criteria:

(1) Articles must be a "crime report", that is when the majority of the article is dedicated to the description of a crime committed after the offender has been identified or arrested and not for example, an article discussing the crime after it has been initially reported (i.e., an Op Ed piece discussing a crime and its implications to society). ${ }^{2}$

(2) Articles must be reporting a crime allegedly committed by a person identified as Gypsy, gypsy, Roma, Romani (or one of the spellings mentioned above).

(3) Articles must adhere to a length of 1-6 pages (approx. 100-200o words in order to parallel articles reporting corporate crimes).

(4) Articles must fall within the time frame of 2004-2012.3

These articles were mostly found in the local news sections of the papers. Types of crimes reported in articles featuring Romanies included petty theft, scams (the majority), burglary, begging and filing a false tax return.

Articles reporting crimes committed by CEOs or Wall Street executives were found by www.google.com searches of CEO combined with the words crime, arrested, accused, charged. Some names that surfaced repeatedly in the searches included Bernard Ebbers (WorldCom), John Rigas (Adelphia), Ken Lay (Enron), Bernie Madoff (Ponzi scheme), Martha Stewart and companies such as Enron, Goldman Sachs, and Peregrine. Because these cases were so well-publicized, they were found in very well-known prestigious American newspapers (online) such as the Wall Street Journal, New York Times, and Washington Post as well as less prestigious but still widely circulated papers such as N.Y. Daily News and Buffalo News. Interestingly, most of the 12 articles reporting crimes by CEOs were found in the business sections (as opposed to local news for Roma reports) which supports Clinard \& Yeager's (2006) findings that nearly all publicity of corporate law violations are found in the business section of newspapers. Articles chosen for analysis ${ }^{4}$ fit the same criteria as in Roma crime reports (except that they had to feature a CEO or Wall Street executive), and in the case of some of the large corporate crimes such as that of Goldman Sachs, several articles were cho- 
sen dealing with the same crime but from different papers. This was done in order to see if political tendencies of newspapers would have an effect on the type of coverage and the portrayal of the offenders. This could not be done in the case of Romani crime reports because coverage was mostly local and found mostly in one source for each crime. Crimes found to be committed by CEOs or corporations included accounting fraud, looting, concealing debt load, conspiracy, securities fraud, insider trading and false regulatory filings. Finally, the articles chosen for this paper were much longer and more detailed than in texts reporting Roma crimes. This could be attributed to the wide coverage of these highly publicized crimes (note that if they were not publicized they would not have been found easily) or because of the devastating effects they had on society. Therefore, although there were only 12 texts (as opposed to the 23 texts found reporting Romani crimes) the entire text size for each group studied remains relatively similar in length.

After the articles were found, they were imported to AntConc 3.2.3 m (qualitative data analysis concordance software) and run through a word list to rank lexical items according to frequency. Once this list was produced, the author examined the list manually searching for patterns and themes. These types were then color-coded, and lexical searches were carried out for examples of metaphor/metonymy, transitivity and use of pronouns (as well as other linguistic and non-linguistic strategies used in the texts). For triangulation purposes, the data was then re-examined manually to determine other lexical choices that might fall into the metaphorical/metonymical categories, and these were run once more through the AntConc coding system. After the patterns and themes appeared examples from the texts were organized under each theme both for Romani and CEO crime reports, and presented in the following results section.

\section{Results}

Results from analysis of both article sets reveal a striking difference in the way crime reports are communicated to the public for Romanies and CEOs. The following sections will discuss these differences and incorporate examples from both groups in order to illustrate the nuanced way in which language is used to present each group differently in media discourse.

\section{Anti-family values vs. family values}

One way that Romanies are presented in crime reports is to emphasize their lack of "family values." Throughout the Romani texts 37 tokens of the word elderly (ranked 27th out of 1963 word types found in the texts) were found pointing to a strategy of highlighting crimes against the elderly. This strategy was effective in reinforcing a negative narrative of Romanies that highlights their supposed lack of family values by disrespecting valued members of society and a large percentage of the readership. Here are some examples from the texts:

Text 3: A Lake County tip launched a Polk County undercover operation that detectives said caught five gypsies who were targeting elderly victims.

[...] "Many of them have already fled this area like cockroaches when you turn on the lights. So, they're going to settle in some other part of the state," Judd said.

Text 4: The sheriff's office says she is legendary in the gypsy culture for preying on older people. "The elderly people with any type of money certainly are the most vulnerable, most trusting, in our society and these are the type of people you need to watch out for," an undercover agent said. 
Text 6: Experts say it's been the busiest summer ever in Chicago for what police call "Gypsy" scams, and senior citizens everywhere need to watch out.

The above examples reveal a tendency to overuse metonymies for the elderly such as older people, senior citizens, and elderly victims which puts forth a narrative that Romanies are "out to get" elderly people. The only other content word (e.g., nouns, adjectives, adverbs, verbs) that ranked higher than elderly in the text file was that of police (ranked 24th) which calls attention to another strategy in the texts; the over-representation of the "crime definers" and the influence law enforcement has on how crime reports are brought to the public. The below examples demonstrate the attempt by law enforcement to "create an image of themselves as an efficient and effective force, as this ensures public support" (Mayr \& Machin, 2012, p. 138).

Text 14: An eagle-eyed Old Brookville cop caught two suspected cat burglars red-handed after pulling over a car that had been linked to several Gold Coast break-ins, police said.

[...] Keteltas, whose father, Thomas, is a detective in the Nassau County Police Department's second squad, called his collar "very satisfying." "It's part of the job. That's what we are here for, taking criminals off the street," he said.

The examples above highlight the positive traits of the police officers, including the fact that the officer is part of a police family, and feelings about his professional accomplishments. Moreover, use of law enforcement jargon such as collar (referring to the act of apprehending a criminal) creates intimacy between the reader and the law enforcement officials reporting the crime. The overwhelming presence of law enforcement found in the texts (represented by 63 lexical items including officers, authorities, sheriff, detective, police, etc. [...]) points to a trend in news management in which recent technological advances (such as the convenience of iPhones and social media such as Facebook) have meant that the police have become far more accountable (Mayr \& Machin, 2012, p. 138). As a consequence, they have professionalized their media management strategies, some of which are borrowed from the corporate sphere (Ibid, p. 138) and work with journalists in a symbiotic relationship in which journalists benefit from the easily-obtained information about the crimes, and the police (and other law enforcement agencies) benefit from having their view of the crimes brought to the public. As a result, "what we encounter as crime news, therefore, comes in the first place not from the experiences of the victims of the crime [...] but from the bureaucratic process of the police, the courts and the local authorities" (Mayr \& Machin, 2012, p. 142). Nowhere is this strategy more evident than in the Romani crime reports in which out of 23 reports, only one features the voice of a Romani offender, and all 23 crime reports include reference to law enforcement and often direct quotations from them.

There are several other linguistic strategies present in the above texts besides the obvious forefronting of crimes against the elderly vs. the positive image of the police. First, the use of deictics (words such as that, this, them, us, here, there used for purposes of positioning groups in a power structure) is employed in Text 4 to separate between "us" and "them" by giving value to the elderly in our society and noting that these are people to watch out for (Petersoo, 2007b; van Dijk, 1993, p. 264). Secondly, there is the use of words such as prey and cockroaches (Text 3 ) that create the metaphor ROMANIES ARE ANIMALS and again support the narrative of Romanies on the "hunt" for the elderly. Finally, the use of metonymies such as gypsies, gypsy culture 5 and Gypsy scams reveal the lack of education on the part of the 
journalist and those reporting the crime as to the fact that "Gypsy" is an ethnic group (and thus should be capitalized). Use of terms such as gypsy scam and gypsy fraud, and references to Roma offenders as scammers and scam artists (commonly found in the texts) make connections between crimes and the Romani ethnic group (referred to mostly as Gypsies in the texts) and come with surface frames that latch onto and activate deep frames related to our moral values and emotions. "When repeated over and over, the words reinforce deep frames by strengthening neural connections" (Lakoff, 2006, p. 102). These repetitions then create metaphors (that lead to stereotypes) of ROMANIES ARE CRIMINALS, and hence, Gypsy or Roma/Romani, comes to index crime. Thus, as Michael Silverstein describes, the words are "just the tools of communication, used to index all sorts of things, which get layered on top of one another" and are continually strengthened and reinforced in the public's social cognitions and perception of these groups with each report (Silverstein, 2013). In the case of Romani crime reports analysed for this paper, the linking/indexing of crime with Romanies takes on a second order of indexicality whereby an iconic/metaphorical relationship is presupposed or entailed (i.e., ROMANIES ARE CRIMINALS), which allows this metaphor to be used as a stereotype (Silverstein, 2003).

Terms frequently found in media discourse such as gypsy scam and gypsy fraud can be traced back to law enforcement officers such as Detective Dennis Marlock. One of the most vociferous crusaders against "Gypsy crime" Detective Marlock of the Milwaukee Police Department and president of Professionals Against Confidence Crime maintained the Fraud Tech website and gave frequent lectures to police departments around the country on this topic. ${ }^{6}$ In order to confirm his far-reaching influence over law enforcement attitudes and procedures in the United States, visit www.google.com and type in Gypsy crime, Gypsy fraud or Gypsy scam. Articles within law enforcement journals and papers refer frequently to his incorrect statements and racial bias about the Romani people (Getsay, 1983, p. 59; Sandland, 1996, p. 384). Det.Marlock defines Gypsy as "a criminal lifestyle of thievery and deception dating back to 1000 A.D." and until confronted with his inaccuracy, did not seem to be aware of the fact that Gypsy is an ethnicity and not a lifestyle (Hancock, 2010, p. 4). If instead the term Gypsy in Gypsy crime were exchanged for African-American or Latino, this would not be tolerated, yet in 2012, the legitimization of these terms still persists and is frequent in media reports of these crimes. According to Ian Hancock:

\footnotetext{
The targeting of Gypsies as a group, and the maintenance of unconstitutional legislation singling Gypsies out in state and country by-laws, and arguably the existence of ethnicity-specific police "task forces" can be traced to one Dr. Cesare Lombroso, a professor of psychiatry and criminal anthropology at the University of Turin, whose book, Crime: Its Causes and Remedies (Boston, 1918) served as a basis for American legal attitudes and a model for law enforcement manuals in this country until 1940. (2010, p. 9).
}

In this book, Romanies are referred to as a "living example of a whole race of criminals." This association of race with behavior is unfortunately still supported by law enforcement (as illustrated by the above examples) despite the fact that evidence does not support this claim. A case in point is the rape and murder rate for Romanies in the U.S., which is much lower than the national average (Hancock, 2010, p. 17). However, as of yet no acknowledgment has been made of the fact that "since the very founding of our country Romanies have been excluded by law from participating in the larger society, and have had to exist as a marginalized people in America" (Hancock, 2010, p. 9). ${ }^{7}$ As such, the relationship between Romanies and law enforcement has been one of distrust and many Romani Americans feel targeted by law enforcement (Kates \& Gergely, 2011). 
In the following two examples a theme commonly found in research on Italian crime reports (see Catalano, 2011b) surfaces in which Romanies are presented as lacking in parenting skills and family values. This form of denigration is implied by the clause (Text 18), who is the father to the child, which normally would be assumed since he is the husband of the woman with the baby. In addition, the final dependent clause at the end of the example from Text 19 hints at the idea that a larger group of gypsies might be using the woman and her child to get money, although there is no evidence of this presented in the report.

Text 18: As the investigation concluded, the woman's husband who is the father to the child arrived and protested the arrest of his wife and the protective custody of their child.

Text 19: At the time of the story, there wasn't any way to confirm that she was connected to a larger group of gypsies, who might be using the women and children to get money.

When examining reports about CEO crimes, we are told a different story, one that points to family values, religion and support. The following examples from CEO texts demonstrate this tendency to portray CEOs as "family men" by highlighting their family relationships, friendships with the elderly, and support from religious members of the community.

Text 1: (John Rigas) The elder Mr. Rigas spoke hoarsely and hunched over as he pleaded for leniency, and his family wept quietly as he was sentenced.

Upon leaving the courtroom, John and Timothy Rigas diverged to opposite sides of the hallway - the son huddling with his lawyers on one end while the father, looking overwhelmed, congregated with family on the other. "You did a very nice speech up there," said an elderly friend, hugging John Rigas.

Text 3: "All of his family members grew up with this being our lives. When it is a family operated business you don't go home at night and shut everything off.

Text 5: (Bernard Ebbers) His wife, Kristie, cried quietly throughout the reading of the verdict, and, after it was finished, Ebbers walked over and put his arms around her and their daughter.

Text 8: (Kenneth Lay) Once jurors and the judge cleared out of the courtroom,Mr. Lay's family members huddled around him.

Two local ministers also leaned in and hugged Mr. Lay, whose family members soon formed a circle in the courtroom, with arms over shoulders, and cried together.

The above use of terms such as wife, daughter, son, elderly friend, family members, etc. [...] create the metaphor CORPORATE AMERICA IS LIKE A FAMILY in which the metaphorical process of transferring certain qualities from one sign to another (those with family values and close family relationships to those of CEOs/Corporate America) occurs. As a result of this process, the targets (CEOs) have now taken on properties they didn't have before (Thwaites, Davies \& Mules, 2002, p. 51). Since according to this metaphor, to reject the ideals of corporate America would be to reject family values, the concept of the CEO is now embedded in positive myth and stands in sharp contrast to common metaphors found in the Romani texts such as ROMANIES ARE CRIMINALS and ROMANIES ARE ANIMALS. 


\section{Othering vs. One of us}

Another potent element present in the texts is that of "Othering" which reveals an underlying ideology of xenophobia and racism referred to as "xeno-racism" by Krzyzanowski \& Wodak. "Xeno-racism" denotes a new form of racism found in public discourse regarding migrant issues which is xenophobic in form, but racist in substance and "disguises a stronger opposition to migrants and the continuation of racism in a new guise" (2009, p. 2). While the notion of xeno-racism has its origins in a post-Nazi society that still only allows citizenship by blood/jus sanguinis (rather than jus soli), I will argue that it is also relevant for understanding the discourse in the U.S. and Canada with respect to migrants. This "new racism" is no longer expressed in overtly racist terms (because it is rarely acceptable in mainstream media), for instance, by reference to some notion of biological or racial superiority, white supremacy, or skin color. Instead, cultural or social characteristics (such as "doesn't have a steady job", or "not wanting to integrate") (Wodak \& van Dijk, 20oo, p. 366, 367) are employed to discriminate between citizens and migrants. The following examples are just a few of the many instances of "Othering" and xeno-racist discourse found in the texts (note that elements that illustrate "Othering" have been bolded):

Text 11: "Some of them had addresses in the Chicago area," said Ballwin Police Sgt. Jim Hel-
dmann. "They described themselves as gypsies, they have ties to European countries, we be-
lieve Russia."

Text 12: "There are these roving groups of gypsies, for lack of a better word, that have no ties to a specific area but commit these types of crimes until the community becomes aware of it and then they move on before they get caught," he said, noting there was no evidence the pair were part of the Romani ethnic group.

Text 14: May described the duo as "transients or travelers." He said they are believed to be part of a nomadic band of thieves that migrate from Florida up the East Coast each spring, when it becomes easier to burglarize homes during the day as homeowners spend more time outside during the warmer weather.

Text 17: "It's a real, live Gypsy from Poland," Atherton police Chief Mike Guerra said at a community meeting Monday night. "They entered the country last year. They came into Chicago and into the Peninsula."

There are several patterns in the examples of "Othering" that are worth pointing out. The first is the use of terminology referring to an itinerant lifestyle. This use of words referring to Romanies as a nomadic people is not uncommon in discourse about Romanies around the world (see Catalano, 2011a; Sigona, 2003, 2005) and creates a common (but inaccurate) metaphor of ROMANIES ARE UNSETTLED. These frequent expressions demonstrate the using of adjectives such as roving and roaming and verb phrases such as have no ties to a specific area which perform the function of "Othering" and erase the fact that although historically Romanies traveled, this was because local laws forbade them to stop. Thus, it was the result of circumstances and not a "genetic" disposition to travel (Hancock, 2002, p. 105). In the United States today, less than 3\% of Romanies are permanent travelers yet the lexical choices mentioned above erase this fact and repeat the notion of Romanies as itinerant and thus different from "Us."

Text 17 provides another example of the lack of education about Romanies and the mention of having seen a real, live Gypsy (consider the phrase "real live African Americans") suggests a "subconscious comparison with storybook Gypsies" (Hancock, 2010, p. 2) and is 
evocative of other rare sightings such as a space alien or circus. In addition, these quotes contribute to negative context models that readers already associate with the term Gypsy consistent with Foucault's concept of circular truth, that is, how those in power construct truth (1998).

Another example of "Othering" from the texts, which demonstrates xeno-racist discourse in action, is that of Text 18, in which the use of over-completion is employed (see below).

Text 18: The investigation revealed the unemployed Romanian male and female each possessed several hundred dollars at the time of the contact.

Over-completion is a mode of description referred to as "the level of abstraction" or the "relative degree of completeness" and can often take the form of functional irrelevance. That is, it gives the reader an "irrelevant" detail, but this detail is relevant within a more general negative portrayal of a person or group (van Dijk, 1991, p. 185). This can be understood in light of the violation of Grice's Cooperative Principle and the idea of a maxim of quantity, which dictates that in a dialog we give as much information as is required, and no more than is required. Violations (flouting) of this maxim can serve the purposes of misleading or to provide a specific implicature that is, implying something that is not expressed directly (Lindblom, 2006, p. 178). The use of over-completion in this example is a competent strategy to frame Romanies as "Other" and is accomplished by mentioning the employment status of the husband and wife in the report, something we do not need to know when reporting the crime they were accused of.

In the following examples from recent reports in the Canadian Toronto Sun, overcompletion is used effectively to connect the crimes to the public's concerns about the number of Roma refugee claimants arriving in the Toronto area in the last few years.

Text 5: Additionally, Toronto welfare officials estimate more than \$2 million in benefits was paid to the Romanian immigrants since January.

Text 21: Police from two jurisdictions accuse two couples of conducting distraction thefts and fraud since 2009, just months after touching down at Pearson Airport as claimants from Hungary, where it is alleged they are fleeing persecution [...].

Border officials said the accused are already collecting welfare, housing and other social benefits in Toronto as claimants.

Text 22: Officials said the suspects are Roma refugee claimants from Hungary. Their bids to come to Canada may not be affected if they're convicted of the crime because the offence is considered minor. A sentence of 10-years or more for a serious offence could place their cases in jeopardy, officials said.

In the above examples of xeno-racist discourse, particular attention must be paid here to metonymies such as Roma refugee claimants, Romanian immigrants and claimants. These terms are used strategically to call attention to their most relevant actions and characteristics (or at least what the producers of the text would like to highlight)-being from another country or ethnicity and receiving benefits from the Canadian government. This then backgrounds the fact that,

"The vast majority of Roma who have come here seeking asylum in Canada have tried their absolute best to build better lives here and become a part of our society [...] not at all to take advantage of the system" (Elliot, 2012). 
This narrative of Roma being a burden on society is built on in each of the crime reports from Canada and has contributed to political decisions and support about whether or not Roma refugee claims (particularly from Hungary) should be accepted in Canada. The use of these metonymies and the subtle connection being made between the crimes and refugee benefits is not by chance, and illustrates the systematic use of crime reports in Canadian media discourse as ammunition for politicians to push their agendas. By strengthening public social cognitions of Roma as deviants and criminals, the politicians build their case as to why they should not be allowed into the country or given refugee status. Case and point is Bill C-31 (a.k.a. the Protecting Canada's Immigration System Act), which was passed in June 2012. This new law supposedly speeds up refugee processing by giving the immigration minister the power to designate any country as safe (Cheadle, 2012). The law also allows the detention of "irregular arrivals" - those who arrive by boat, for examplewithout a warrant or an appeal and grants the Minister of Immigration sole authority to set a list of "safe countries," which are deemed to be capable of protecting their citizens. (Balaban, 2012). With this law, Immigration Minister Jason Kenney has "singled out escalating refugee claims from Hungary - the vast majority of which are rejected or simply abandoned-as a symptom of a system in need of an overhaul." As a result, crime reports in Canadian online newspapers provide subtle support for the creation and maintenance of this law (Cheadle, 2012) even though ample evidence exists of the dangerous conditions Roma face in Hungary (as well as other European countries they are fleeing from, such as Romania).

In the case of CEOS, again we see a different type of discourse, where instead of "Othering", CEOs are shown to be like "Us", as in the following examples. ${ }^{8}$

Text 5: Ebbers, a former milkman and high school coach who built WorldCom from a tiny Mississippi long-distance reseller into a national powerhouse [...].

Text 8: In televised remarks he said, "We believe that God in fact is in control and indeed he does work all things for good for those who love the Lord." (said by Kenneth Lay in his defense)

Text 9: Raised in New Jersey in a family of six children, Stewart learned her homemaking skills from her mother and gardening from her father, according to her Web site. She earned a bachelor's degree in history and architectural history at Barnard College and worked as a model to pay her tuition, then became a stockbroker on Wall Street after graduating.

Here again we see a distinct contrast in the discourse with the use of references to jobs that average people might have (milkman, high school coach) religion (Text 8), family and privilege (Text 9). Additionally, in 11 out of 12 CEO crime reports, the voice of the offender is heard through direct quotations (e.g., Kenneth Lay in Text 8 above) or quotations from family or lawyers. Compare this to Romani crime reports in which Romani offenders were heard from in 1 out of 23 texts.

Another frequent linguistic strategy exemplifying "Othering" is that of delegitimization in which characteristics and practices of Romanies are called into question and ridiculed in the texts. The following examples illustrate this strategy:

Text 13: A total of nine charges were filed against Yana Ristick and Michael Evans, who have a child and are considered a married couple within the gypsy community.

Text 8: Rub your body with an egg to cure ovarian cancer. Eat nothing but red fruit for a "spiritual transfusion." And, most importantly, ring up huge bills at ritzy department stores 
to save your dad from a heart attack. You won't find these miracle cures in The Journal of the American Medical Association.

Text 20: Portland is home to roughly 3000 Gypsies, who call themselves Roma. They are a cloistered, cash-on-the-barrelhead community that tends to be mistrustful of banks and checking accounts.

These examples demonstrate how the Romani community is de-legitimized in media discourse from the legal nature of their marital status, to medicinal practices. In Text 8, a Romani woman's home remedies (not unlike some highly respected alternative medicine practices in the U.S.) prescribed to a woman as an alternative cure to cancer are ridiculed. In addition, the author of Text 20 calls into question the way Roma refer to themselves, as if this is just a name invented to throw off the public when their real name is "Gypsies", when in fact it is the opposite. The following comments exemplify the contrasting manner in which cultural practices of CEOs and their families (in particular those of a positive nature) are highlighted in the texts:

Text 2: In May, Madoff's wife, Marion, joined Wilpon's wife, Judy, to raise money for the United Jewish Association Federation in a charity bridge tournament.

Text 3: "Bernard Madoff is a longstanding leader in the financial-services industry with an unblemished record," Mr. Horwitz said in an interview. "He is a person of integrity.

He has made major donations to Democratic candidates and organizations.

These examples not only point out positive characteristics of Bernard Madoff, a person accused of serious crimes and harm to society (such as robbing people of their pensions), but forefront his past positive actions (and those of people associated with him) in society.

\section{Mug-shots vs. Smiles}

Image and text work together in media discourse to send a message to the receiver of the text. In the case of Romani crime reports, the majority of the texts presented an image of the offenders (if any images were shown) in the form of standard mug shots. ${ }^{9}$ Many times the photos show the offenders together in similar backgrounds with similar clothing or in a photo montage (such as in Photo 2$)^{10}$ where all the subjects are pieced together as if in a jigsaw puzzle with the faces enlarged and showing only part of the face and neck. In none of the photos are Romanies seen as agents of anything in particular (other than posing for a standard mug shot). Their faces are not happy, they are not smiling, and they do not present a positive image to the public. Although they are close-up shots, which could convey intimacy, they do not, because they are shown together with the other offenders as part of a group, strongly homogenized through the similar poses and focus on the middle of the face. These images deny Romanies individual characteristics and differences (and thus, feed into negative racial stereotypes) (van Leeuwen, 2008, p. 146)"

One might argue that it is natural that in the genre of "crime report", the subjects would not be seen in a positive light, and that mug shots are standard procedure for media crime reports. However, in comparison to the photos of Romanies, the photos of CEOs are strikingly different and thus debunk this argument. Here the offenders are shown as individuals, usually through intimate photographs, which are close-up pictures of the CEO smiling and interacting with the viewer directly, as in this photo of Bernie Madoff. ${ }^{12}$ Here he is seen as a kind, grandfatherly type looking directly at the viewer from an equal camera angle conveying equality and engaging with the viewers. 
Several different newspapers (of varying levels of prestige and audience such as the New York Daily News and Wall Street Journal) were used for analysis reporting the same crime (i.e., Bernie Madoff), and results reveal that on a continuum of negativity/positivity not surprisingly, the lower prestige and more middle-class newspaper New York Daily News displayed more negative representations of Bernie Madoff than the Wall Street Journal. However, the same overall tendency of positively representing the offender and reducing the language of crime was found to be a pattern in both articles discussing Madoff (both verbally and visually), as well as across CEO crime reports, regardless of the newspaper.

In Photo $4^{13}$ Lloyd Blankfein (CEO of Goldman Sachs) is testifying on behalf of Goldman Sachs in front of the Securities and Exchange Commission (SEC). This photo provides an interesting example of reversal and the semiotic process of erasure in that the accused (Lloyd Blankfein) is shown pointing a finger at what is supposedly the official from SEC that is accusing Goldman Sachs of fraud. Therefore, the underlying message of the photo is not that Lloyd Blankfein or Goldman Sachs is to blame, but instead, the recipient of the finger pointing, that is, the point of focus of the photo, is the government is to blame. This narrative occurs frequently in the data and is reinforced by the transitivity analysis following this section. In addition, these photos provide more evidence for the notion that while the media speak on behalf of the public they are also speaking on behalf of powerful capital interests such as Goldman Sachs. This should not be entirely surprising given the source is the Wall Street Journal, whose readers include among others, Wall Street brokers, bankers and corporate executives. However, similar photos and positive representations were found (albeit to a lesser degree) in newspapers such as the N.Y. Post, which have a less business-oriented readership. In addition, this photo demonstrates the frequent technique found in CEO crime reports referred to by Sykes \& Matza (1957) as "techniques of neutralization", that is, accounts through which deviants mitigate and justify their criminal conduct (Mayr \& Machin, 2012, p. 204). Sykes and Matza developed this theory of delinquency to explain the way in which deviants (and in particular, corporate criminals) deny responsibility among cohorts within their own "subculture of delinquency", and thus permit them to commit crimes without too many pangs of conscience, "through their sanitizing prism, each subculture softens criminal acts so that they assume the appearance of 'not really' being against the law" (Box, 1983, p. 55). Thus by using neutralization techniques (such as denying responsibility, pleading ignorance, denying the victim and condemning the condemners), executives are able to violate the law without guilt and without damaging their respectable non-deviant self image (Ibid). For the purposes of this paper, the term "techniques of neutralization" will refer to the way in which corporate deviants neutralize their actions to the media and the public (as opposed to among their own subculture), through their own comments or those speaking on their behalf. Examples of this technique in the verbal texts will be discussed later.

Photo $5^{14}$ appears in the same article that discusses charges of fraud faced by Goldman Sachs with the upward camera angle conveying the power and stature of the accused firm and the towering building standing for the power of the institution itself. This photo demonstrates how the sign of economic capital may be just as effective as the thing itself (Thwaites, Davies, \& Mule, 2002, p. 198).

The next photograph ${ }^{15}$ depicts Martha Stewart wearing a known sign of wealth (fur) and standing next to a stocky lawyer (another sign of social status) and supports the text's narrative that she is a privileged member of society.

Hence, not only linguistically but also in visual elements are the two groups represented differently, and in the case of CEOs they are naturalized and are represented positively despite the heinous crimes they are accused of in the texts. 


\section{Active vs. Passive}

Another way that both groups are represented differently in the crime reports is through the subtle linguistic process of transitivity. Transitivity (first put forward by Hopper \& Thompson, 1980) is "the system that is concerned with how entities and actions in a situation are coded in the language." (Ryder, 2006, p. 40). Thus, whether a participant in a text chooses a more or less transitive representation of an event, can serve various stylistic functions such as marking point of view, distinguishing text genres and subgenres from each other, and representing characters as powerful and responsible or the reverse (p. 40). Because of this last function, transitivity analysis is especially useful in critical discourse analysis and in particular, the present paper. The following is an analysis calculated using corpus analysis results.

Table 1 demonstrates the systematic activization of (mostly) negative actions carried out by Romanies (e.g., distracted, targeted, committed) and contrasting majority passivization of law enforcement toward Romanies (e.g., is charged, were jailed, has been arrested). Thus by choosing a different type of process (passive vs. active), the author "downgrades" the process and creates a more complex stylistic effect that legitimizes law enforcements' actions. This is in turn a type of metaphorical encoding that recodes Goals (the accused Romanies in this case) as less affected participants and decreases the perceived power of the natural Agent (Ryder, 2006, p. 45). In essence, the negative actions of Romanies are accentuated while the negative actions of law enforcement officers are downplayed. The same occurs systematically in the reverse for CEO negative actions and actions of law enforcement in which the government is placed in a more active role in negative actions against CEOs (see below) and the majority of CEOs' negative actions are presented in the passive.

Thus, the subtle role of grammar is nuanced and difficult to notice on the surface, but in the overall representation of a group it can be a quite potent strategy.

\section{Language of Crime vs. Language of Regret}

Part of a potpourri of strategies of denaturalization, Texts 1 and 6 (below) use terminology normally adopted when talking about terrorists or the Mafia referring to Romani offenders as a gypsy cell, criminal organizations and senior citizen terrorists thus placing the language of crime at the forefront, with the police taking a large role in defining the crimes for the journalist and his/her audience. Here the media's reliance on the "official definitions of crime provided by powerful institutional sources and individuals, which include the police and the criminal justice system as well as politicians (Schlesinger \& Tumber, 1994) is brought to our attention. Again we see the central role police have as crime definers that is reinforced by their close symbiotic relationship with the media (Mayr \& Machin, 2012, p. 168). The following examples demonstrate typical language found in crime reports, with examples from Text 1 and 6 showing a trend to attempt to group Romani crimes as organized found also in crime reports in Italy in which law enforcement used terminology applied to Mafia reports to describe Romani crimes (Catalano, 2011a/b).

Table 1. Activization/passivization of Romani and law enforcement actions.

\begin{tabular}{lrr}
\hline & Active & Passive \\
\hline Total negative actions by Romanies, $\mathrm{n}=151$ & $76 \%$ & $24 \%$ \\
Total negative actions toward Romanies by law enforcement, $\mathrm{n}=103$ & $41 \%$ & $60 \%$ \\
\hline
\end{tabular}


Text 1: They're wanted on charges of participating in a criminal organization and other offences.

[...] The gypsy cell enlisted people from Romania for the crime ring and investigators have identified more than 400 people who were associated with the criminal organization.

Text 5: Major gypsy crime ring broken near Toronto.

Text 6: "I call them terrorists. They're senior citizen terrorists in my opinion," said Westchester Police Chief April Padalik.

On the other hand, the language of crime is almost completely absent in the CEO crime reports. According to Minkes \& Minkes, corporate crime (the deviant activities of respectable institutions, corporations and individuals) "has been relatively neglected in the study of crime and deviance, although it is a widespread problem in all contemporary societies" and "far more costly for society than other kinds of crime" (2010). There is far less information about corporate crime available to the public and corporate crime is not so easily provided to journalists by the usual definers of crime (the police) (Mayr \& Machin, 2012, p. 199). When considering this fact, one must note that the mass media are themselves owned by corporations funded by yet other corporations (the advertisers), and governments tend to make laws that favor corporations. Hence, it is not surprising that powerful individuals representing powerful companies are represented favorably in the media (Ibid, p. 222). What is surprising, however, is the nuanced way in which this is accomplished linguistically in such a manner that it is not largely picked up on by the average reader. The following examples illustrate the typical language of CEO crime reports and the "ways the corporate origins and nature of corporate crimes are obscured through the language used in the media and by corporations themselves" (Ibid, p. 202).

Text 1: "To my stockholders, I apologize - this whole thing has happened to all of us," he said. "There are many things that I wish I had done differently."

Text 2: When the agents showed up at his apartment, Madoff admitted he'd "paid investors with money that wasn't there," was "broke" and knew "it could not go on."

Text 6: Goldman's trading allowed the firm to weather the financial crisis better than most other big banks [...].

[...] The civil charges filed by the Securities and Exchange Commission are the government's most significant legal action related to the mortgage meltdown that ignited the financial crisis and helped plunge the country into recession.

Text 7: CEO Lloyd Blankfein has drawn heat for Goldman's rich pay and profits in the wake of the taxpayer bailout of the financial system [...].

The civil charges against Goldman [...] represent the government's strongest attack yet on the Wall Street dealmaking [...]

Text 10: The executives were accused of understating the level of high-risk subprime mortgages that Fannie and Freddie held just before the housing bubble burst [...].

"The SEC is wrong, and I look forward to a court where fairness and reason-not politicsis the standard for justice."

Text 12: The head of collapsed brokerage firm Peregrine Financial Group Inc. admitted to defrauding clients out of more than $\$ 100$ million over nearly 20 years by personally doctoring bank statements and duping auditors with the help of a post-office box, federal prosecutors said Friday. 
The above comments demonstrate techniques of neutralization in which corporate deviants (and those speaking on their behalf) use metonymy and nominalization to strategically mitigate and justify their criminal conduct to the public. For example, in Text 1, John Rigas employs the metonymy this whole thing to refer to the act of stealing hundreds of millions of dollars from the company and lying to his clients. Compare this to the words international crime ring used to refer to $\$ 85$, ooo seized from Romanies. In Text 2 we see paid investors with money that wasn't there instead of what might be referred to Romani crime reports as stealing or lying. Text 7 uses metaphor and metonymy combinations (has drawn heatheat stands for anger) to show how Goldman is the victim of the government's anger, and refers to their illegal activities (not to mention unethical) of paying themselves exorbitantly in the aftermath of the financial crisis (and government bailout) as rich pay and profits. Text 10 refers to the CEOs lying about how many sub-prime mortgages the company had using the word understating, and in Text 12, the word defrauding is used to describe stealing. In addition, the nominalization of defrauding represents a systematic linguistic process common in the crime reports in which the action defrauded is transformed into a less powerful gerund form defrauding, which downgrades the role of the agent (the CEO). Thus. Although CEO crimes consisted of accounting fraud, looting, concealing debt load, conspiracy, securities fraud, insider trading and false regulatory filings that resulted in serious damaging consequences such as people losing their jobs and pensions and perhaps even the financial crisis (in the case of Goldman Sachs), and affected millions of people worldwide, the crimes were not framed as such and the social harm they caused was downplayed and backgrounded. In contrast, Roma crimes largely consisted of petty theft, scams and burglary, and affected a relatively small range of people. Nevertheless, headings and text examined for this paper reveal an overwhelming bias in their reporting which foregrounds and emphasizes the effects on the victims and represents Romanies in a negative light.

In summary, the above examples illustrate the use of non-crime news frames by using language that would not normally be applied to crimes (such as rich pay, whole thing, paid investors [...]). Regardless of the type of newspaper examined, results reveal the same overall tendency of neutralization and reduced use of the language of crime in the portrayal of CEOs in crime reports. For example, the official definers of crime (law enforcement) are largely absent from the reports replaced by government agencies such as SEC, which are in turn vilified through the use of transitivity and lexical items creating metaphors of war, (e.g., attacked) to describe their actions. In this manner, the characteristics of enemy combatants are mapped onto the government. This is an example of what Mayr \& Machin refer to as condemning the condemners, a technique used to deny the legitimacy of the law regulating CEO behavior as well as the competence of those enforcing the law (2012, p. 204). As part of this strategy, the financial crisis is referred to in metaphors of an unavoidable casualty or supernatural event (Text 6), which is effective in dispersing the blame. After all, how can Wall Street executives and bankers be responsible for an unforeseen natural disaster or force majeure? Thus, unlike in Romani crime reports where articles are found in local news sections and are ripe with lexical items normally associated with crimes, in CEO crime reports, we the public, are often left wondering what the crime was, and perhaps if it ever was a crime.

\section{Discussion/conclusion}

Despite the fact that conditions for Romanies are much better in the United States and Canada than most places in the world today, the present paper has demonstrated that Romanies are still represented in a negative light in U.S. and Canadian crime reports. On the other 
hand, CEOs that have committed heinous crimes that have had dire effects on society and the nation's economy have been represented positively, while the crimes they have committed have been consistently minimized, so much so that it is often difficult to recognize the reports as part of the crime news genre. Commonplace news genres such as crime reports are especially dangerous because the public often wrongly perceives them as un-biased presentations of the facts. Nevertheless, crime reports often contain ideologies disguised as neutral reports of the truth and are controlled by dominant forces using the reports to push political agendas or put forth good impressions of themselves. In the case of the Roma, the naturalization of law enforcement together with the denaturalization of Romanies reinforces the metaphor of ROMANIES ARE CRIMINALS, which contributes to the stereotyping of newly arriving Romanies and Romani-Americans in the U.S. and Canada, and the public's perception of this group as a burden to society. As a result, newly arrived Roma refugees are placed in the dangerous position of being forced to return to harmful conditions in Europe. To the contrary, CEOs and their corporations are thriving in today's society, their ever present power growing in force and influence, and nowhere is this so easily recognized than in the genre of crime reports.

The major contribution of the present paper is situated in the ability of critical linguistic analysis to provide insights into crime due to its power to draw attention to the details found in texts (Mayr \& Machin, 2012, p. 225). Tools such as Critical Discourse Analysis and Cognitive Linguistics are essential to understanding the central role of language in the denaturalization and naturalization of groups in crime reports by bringing details such as use of transitivity, metaphor, metonymy and visual elements to the forefront. Furthermore, a critical linguistic analysis makes clear the role of language in the suppression of details and real causes such as the connection of crime to social processes, forces and changes (Ibid, p. 226). These details illustrate that how we talk about a group makes a difference in how they are perceived by the public.

Hence, this paper has made evident that the stereotyping of Romanies still exists in the United States and Canada and needs to be addressed by mainstream media. In addition, further research is recommended that explores the representation of Romanies in other genres such as political discourse occurring in the Canadian parliament regarding immigration issues and entertainment such as T.V. shows like American Gypsies and their role in public perceptions and policies toward Roma. Finally, though there are many other factors involved in achieving equality for all citizens, we must recognize that unless we change the way we talk about the Roma and Wall Street/CEOs in media discourse, the cycle of social injustice will not be broken.

Acknowledgments - The author would like to thank Grace Fielder for her continued guidance and wisdom (particularly in regards to Silverstein's work), Ian Hancock and Staci Strobi for their encouragement and the reviewers whose insightful comments greatly ameliorated this paper.

\section{Notes}

1. Denaturalization can be defined as the act of making something appear less natural or less human which functions to "subordinate other living creatures to human beings" and "to justify denigration of certain groups of people" (Santa Ana 1999, p. 201).

2. The selection of "crime reports" as opposed to articles discussing opinions about crimes was strategic in order to demonstrate the ideology-carrying capacity of news genres that the public generally considers to be "fact-giving" and not "opinion-giving", which makes the deconstruction of these texts much more necessary.

3. Articles were selected within this time frame in order to limit the number of texts due to the scope of the paper, and to keep texts files in parallel time frames. 
4. In order to keep article file sizes relatively parallel, the first 12 articles found reporting CEO crimes (and fitting the criteria for selection used for Roma reports) were chosen.

5. Note that the use of the "little g" gypsy (as opposed to Gypsy) is an indicator that the author does not understand that Gypsy refers to an ethnicity because if he/she did, the convention would be to capitalize the word.

6. In the Romani Archives and documentation Center at The University of Texas there is a flyer listing over 25 presentations on "Gypsy crime" scheduled for one year by different police department specialists.

7. By "our country" the author is referring to the United States. In Hancock's article, many examples of laws (most of which have been repealed) that have been in place in the United States which have led to mistrust of police (mostly relating to Romanies being allowed to settle in a particular area) are listed. Here are a few examples from Hancock, 2010. For more, see Hancock (2010) and Hancock (1987). After the passage of this act, it shall be unlawful for any ... gypsies ... to ... settle within the limits of any county of this state [without having first obtained a yearly license to do so] (Pennsylvania Statutes, Section 11810). Any person may demand of any ... gypsies that they shall produce or show their license issued within such county, and if they shall refuse to do so ... he shall seize all the property in the possession of such [Gypsies] (Pennsylvania Statutes, Section 11803).

8. Text 5 discussesWorldCom's Bernard Ebbers and his conviction of conspiracy, securities fraud and false regulatory filings, Text 8 reports the conviction of Enron's Kenneth Lay (speaking on his behalf) and Jeffrey Skillings for fraud and conspiracy and Text 9 describesMartha Stewart's conviction for insider trading.

9. To view Photo 1, click on the following link: http://chicago.cbslocal.com/2011/12/o2/fivegypsies- accused-of-ruse-burglary-targeting-seniors/ This article (Text 10) was accessed on September 1, 2012

10. To view Photo 2, click on the following link: http://www.kmov.com/news/crime/Gypsiesaccusedof-stealing-up-to-40-iPhones-from-Ballwin-store-157591605.html This article (Text 11) was accessed on September 1, 2012

11. Action verbs were identified through the corpus analysis and then manually counted as passive or active by the author.

12. To view Photo 3, click on the following link: http://online.wsj.com/article/SB1229030101730 99377. html This article (Text 3 ) was accessed on September 1, 2012

13. To view Photo 4, click on the following link: http://online.wsj.com/article/SB1000142405270230349 $1304575187920845670844 . h t m l$ ?mod=WSJ hpp LEFTTopStories This article (Text 7 ) was accessed on September 1, 2012

14. To view Photo 5, click on the following link: http://online.wsj.com/article/SB1000142405270230349 $1304575187920845670844 . \mathrm{html}$ ?mod=WSJ hpp LEFTTopStories This article (Text 7) was accessed on September 1, 2012

15. To view Photo 6, click on the following link: http://www.washingtonpost.com/wp-dyn/articles/ A33685-2004Mar5 2.html This article (Text 9 ) was accessed on September 1, 2012

\section{About the Author}

Theresa Catalano has a PhD in Second Language Acquisition and Teaching from the University of Arizona. She is currently Assistant Professor of Second Language/Applied Linguistics at the University of Nebraska-Lincoln.

\section{References}

Agger, B. (1998). Critical theory, poststructuralism, postmodernism: Their sociological relevance. Illuminations. Arlington: University of Texas. Retrieved from http://www.uta.edu/huma/illuminations

Balaban, K. (2012). Roma refused: Changes to refugee law shut doors to persecuted minority. Toronto Media Coop. Retrieved from http://toronto.mediacoop.ca/story/roma-refused/10555

Box, S. (1983). Power, crime and mystification. London: Tavistock.

Catalano, T. (2011a). Xeno-racism and discursive construction of "us" vs "them": Cosa nostra, wall street, and immigrant. (PhD dissertation). University of Arizona, Tucsan, AZ. Retrieved from http://arizona.openrepository.com/arizona/bitstream/10150/145423/1/azu etd 11550 sip1 m.pdf 
Catalano, T. (2011b). Romanies and the Mafia: “Us” vs. “Them” in Italian crime reports. Presentation given at the Inaugural Romani Studies Conference, Berkeley, CA, November 10.

Cheadle, B. (2012). Bill C-31: "Gypsy Fiction" being Fanned By conservative refugee legislation, Roma advocate says. Huffington Post. Retrieved from http://www.huffingtonpost.ca/2012/05/03/bill-c-31gypsy-roma n $1476059 \cdot$ html

Clinard, M. B., \& Yeager, P. (2006). Corporate crime. New Brunswick, NJ: Transaction.

Dirven, R., Polzenhagen, F., \& Wolf, H. G. (2007). Cognitive linguistics, ideology and critical discourse analysis. In D. Geeraerts \& H. Cuyckens (Eds.), The Oxford handbook of cognitive linguistics (pp. 1222-1240). Oxford: Oxford University Press.

Elliott, L. (2012, October 17). Hungarian Roma refugee claimants targeted in CBSA report. CBC. Retrieved from http://www.cbc.ca/news/canada/story/2012/10/17/pol-cbsa-project-saraimmigrantshungary-roma.html

Fairclough, N. (1999). Global capitalism and "Critical awareness of language." Language Awareness, $8(2), 71-83$.

Fairclough, N. (200o). Discourse, social theory, and social research: The discourse of welfare reform. Journal of Sociolinguistics, 4(2), 163-195.

Ferrell, J., Hayward, K., \& Young, J. (2008). Cultural Criminology: An invitation. London: Sage.

Foucault, M. (1981). The order of discourse. In R. Young (Ed.), Untying the text: A post-structural anthology (pp. 48-78). Boston, MA: Routledge \& Kegan Paul.

Gee, J. (2011). An introduction to discourse analysis: Theory and method. New York, NY Routledge.

Gelbart, P. (2012, January 4). Gadjology: A brief introduction. Presentation given at the Romani Studies Conference, Berkeley, CA, November 10, 2012. Retrieved from http://www.youtube.com/ watch?v=cupzfwqsoLE

Getsay, T. (1982). Gypsy crime. Kansas State FOP Journal, 1(2/3), 18-30.

Guerrero, H. (2009). Colombia bilingüe: Access for all? (PhD dissertation). University of Arizona, Tucson, AZ.

Hall, S. (1992). The west and the rest: Discourse and power. In S. Hall \& B. Gieben (Eds.), Formations of Modernity (pp. 275-331). Open University: Polity Press.

Hart, C. (2010). Critical discourse analysis and cognitive science: New perspectives on immigration discourse. London: Palgrave Macmillan.

Hancock, I. (1987). The pariah syndrome: An account of gypsy slavery. Ann Arbor: Karoma.

Hancock, I. (1994, April 14). On the origin and current situation of the Romani population in Europe and the responsibility of the American media to make that situation known. Report before the congressional human rights hearing on abuses against gypsies in Eastern Europe, Washington, DC.

Hancock, I. (2002). We are the Romani people: Ame sam e Rromane dzene. Hatfield: The University of Hertfordshire Press.

Hancock, I. (2010). Gypsy Mafia, Romani Saints: The racial profiling of Romani Americans. In D. Karanth, (Ed.), Danger! Educated gypsy: Selected essays by Ian Hancock (pp. 195-211). Hatfield: The University of Hertfordshire Press.

Hart, C. (2010). Critical discourse analysis and cognitive science: New perspectives on immigration discourse. London, UK: Palgrave.

Hayward, K., \& Presdee, M. (Eds.) (2010). Framing crime: Cultural criminology and the image. Abingdon: Glasshouse-Routledge.

Kates, G., \& Gergely, V. (2011, April 7). For Roma, life in US has challenges: People commonly known as 'Gypsies' face stereotyping, discrimination. Voice of America. Retrieved from http://www.voanews. com/content/for-roma-life-in-us-has-challenges-119394819/163156.html

Kövecses, Z. (2006). Language, mind, and culture: A practical introduction. Oxford: Oxford University Press.

Kress, G., \& van Leeuwen, T. (1996). Reading images: The grammar of visual design (2nd ed. 2007). London: Routledge.

Krzyzanowski, M., \& Wodak, R. (2009). The Politics of exclusion: Debating migration in Austria. New Brunswick, NJ: Transaction.

Lakoff, G. (2006). Thinking points: Communicating our American values and vision. NewYork, NY: George Lakoff and the Rockridge Institute. 
Lakoff, G.,\&Johnson, M. (1980). MetaphorsWe Live By (2nd ed. 2003). Chicago, IL: The University of Chicago Press.

Lee, R. (1998). Roma in Canada. Retrieved from http://www.romatoronto.org/facts_canada.html

Lindblom, K. (2006). Cooperative principle. In Encyclopedia of Language and Linguistics (2nd ed.) (pp. 176-183). Amsterdam: Elsevier. doi:10.1016/Bo-08-044854-2/oo311-4

Lyng, S. (1990). Edgework: A social psychological analysis of voluntary risk taking. American Journal of Sociology, 95, 887-921.

Meyer, M. (2001). Between theory, method, and politics: Positioning of the approaches to CDA. In R.Wodak \& M. Meyer (Eds.), Methods of critical discourse analysis (pp. 14-31). London: Sage.

Mayr, A., \& Machin, D. (2012). The language of crime and deviance: An introduction to critical linguistic analysis in media and popular culture. London: Continuum International Publishing Group.

Minkes, J., \& Minkes, L. (2010). Tax fraud and benefit evasion. In T. Bennett, F. Brookman, M. Maguire \& H. Pierpoint (Eds.), Handbook on crime. Cullompton: Willan.

Presdee, M. (1994). Young people, culture and the construction of crime: Doing wrong versus doing crime. In G. Barak (Ed.), Varieties of criminology readings from a dynamic discipline (pp. 179-87). London: Praeger,

Presdee, M. (200o). Cultural criminology and the carnival of crime. London: Routledge. Ryder, M. E. (2006). Transitivity: Stylistics approaches. In Encyclopeida of language and linguistics (2nd Ed.) (pp. 40-46). Amsterdam: Elsevier. doi:10.1016/Bo-08-044854-2/00561-7

Sandland, R. (1996). The real, the simulacrum, and the construction of "gypsy" in law. Journal of Law and Society, 23(3), 383-405.

Santa Ana. (1999). Like an animal I was treated: Anti-immigrant metaphor in US public discourse. Discourse and Society, 10, 191-224.

Schlesinger, P., \& Tumber, H. (1993). Fighting the war against crime: Televsion, police and audience. British Journal of Criminology, 33(1), 19-32.

Scollon, R. (2001). Mediated discourse as social interaction. London: Longman.

Selley, C. (2012, October 12). How Europe's Roma problem became ours. National Post. Retrieved from http://fullcomment.nationalpost.com/2012/10/12/ chris-selley-how-europes-roma-problembecame-ours/

Sigona, N. (2003). How can a "Nomad" be a "Refugee"? Kosovo Roma and labeling policy in Italy. Sociology, 37(1), 69-79.

Sigona, N. (2005). Locating "The Gypsy Problem." The Roma in Italy: Stereotyping, Labelling and "Nomad Camps." Journal of Ethnic and Migration Studies, 31(4), 741-756.

Silverstein, M. (2003). Indexical order and the dialectics of sociolinguistic life. Language and Communication. 23, 193-229.

Silverstein, M. (2013, February 18). Interview on School for Linguists website. In Which I interview an article: Silverstein on indexical order. Retrieved from http://schoolforlinguists.wordpress. com/2013/o2/18/in-which-i-interview-an-article-silverstein-on-indexical-order/

Sykes, G., \& Matza, D. (1957). Techniques of neutralization: A theory of delinquency. American Sociological Review, 22, 664-670.

Szandelszky, B. (2012, September 15). Stop vilifying Roma refugees. The Star. Retrieved from http:// www.thestar.com/opinion/editorialopinion/article/1257206--stop-vilifying-roma-refugees

Tajfel, H., \& Turner, J. C. (1985). The social identity theory of intergroup behavior. In S. Worchel \& W. G. Austin (Eds.), Psychology of intergroup relations (2nd ed., pp. 7-24). Chicago, IL: Nelson-Hall.

Thwaites, T. Davies, L., \& Mules, W. (2002). Introducing cultural and media studies: A semiotic approach. Houndmills: Palgrave.

Tyson, L. (2006). Critical theory today: A user-friendly guide. New York, NY: Routledge. van Dijk, T. A. (1991). Racism and the press. London: Routledge.

van Dijk, T. (1993). Elite discourse and racism. London: Sage.

van Dijk, T. (1993b). Principles of critical discourse analysis. Discourse and Society, 4(2), 249-283.

van Dijk, T. (20o1). Multidisciplinary CDA: A plea for diversity. In R. Wodak \& M. Meyer (Eds.), Methods of critical discourse analysis (pp. 95-120). London: Sage.

van Leeuwen, T. (2008). Discourse and practice: New tools for critical discourse analysis. Oxford: Oxford University Press. 
Webley, K. (2010, October 1). Hounded in Europe, Roma in the US keep a low profile. Time. Retrieved from http://www.time.com/time/nation/article/o,8599,2025316,00.html

Wetherell, M. (2003). Themes in discourse research: The case of Diana. In M. Wetherell, S. Taylor \& S. Yates (Eds.), Discourse theory and practice: A reader (pp. 14-29). London: Sage.

Wodak, R. (2001). The discourse-historical approach. In R. Wodak \& M. Meyer (Eds.), Methods of critical discourse analysis (pp. 63-94). London: Sage.

Wodak, R., \& Meyer, M. (Eds.). (2001). Methods of critical discourse analysis. London: Sage.

Wodak, R., \& van Dijk, T. (200o). Racism at the top: Parliamentary discourses on ethnic issues in six European states. Amsterdam: Drava Verlag.

\section{Appendix A: Texts used in the corpus}

\section{Crime reports featuring Romanies}

Text 1: Connor, K. (2012, September 5). International Roma crime ring busted, say police. Toronto Sun. Retrieved from http://www.saultthisweek.com/2012/og/o5/ international-roma-crime-ringbusted-say-police

Text 2: Pleasant, M. (2012, January 12). Deputies arrest four "Gypsies" in roofing scam. The Ledger. Retrieved from http://www.theledger.com/article/20120112/news/120119783?p=1\&tc=pg

Text 3: Gypsy scam artists target Polk County elderly. (2012, January 13). WFTV.com. Retrieved from http://www.wftv.com/news/news/local/gypsy-scam-artists-target-polk-county-elderly/nGMfc/

Text 4: Gypsy woman on the run for years arrested. (2010, May 7). WFTV.com. Retrieved from http:// www.wftv.com/news/news/gypsy-woman-on-the-run-for-years-arrested/nFDtC/

Text 5: Major gypsy crime ring broken near Toronto. (2012, September 16). UPI. com. Retrieved from http://www.upi.com/Top_News/World-News/2012/og/o6/ Major-gypsy-crime-ring-brokennear-Toronto/UPI-96111346938789/

Text 6: Placko, D. (2012, July 18). 'Gypsy' scammers hitting Chicago area hard this summer. Fox 32 News. Retrieved from http://www.myfoxchicago.com/story/19059640/ gypsy-scammershitting-chicago-area-hard-this-summer

Text 7: Boniello, K. (2010, August 1). 35oG bilk on gramps. New York Post. Retrieved from http://www. nypost.com/p/news/local/manhattan/bilk_on_gramps_YZ4IvobBhzcZMnPrWNADfO

Text 8: Beasley, A. (2010, March 16). Broward deputies: 'Gypsy swindler' conned woman out of \$298,ooo. The Palm Beach Post. Retrieved from http://www.palmbeachpost.com/news/news/ crime-law/broward-deputies-gypsy-swindler-conned-woman-out-1/nL5S6/

Text 9: Gypsy "Sweetheart Swindler" busted at downtown funeral home. (2010, May 7). West Orlando News Online. Retrieved from http://westorlandonews.com/2010/05/07/ gypsysweetheart-swindler-busted-at-downtown-orlando-funeral-home/

Text 10: Five 'Gypsies'accused of ruse burglary targeting seniors. (2011, December 2). CBS Chicago. Retrieved from http://chicago.cbslocal.com/2011/12/02/ five-gypsies-accused-of-ruseburglary-targeting-seniors/

Text 11: Gypsies accused of stealing up to 40 iPhones from Ballwin store. (2012, June 6). KMOV.com St. Louis. Retrieved from http://www.kmov.com/news/crime/Gypsies-accused-of-stealing-up-to40-iPhones-from-Ballwin-store-157591605.html

Text 12: Walsh, J. (2010, February 4). 2 burglars target boro elderly. New York Post. Retrieved from http://www.nypost.com/p/news/local/queens/ burglars target boro elderly AOVc5sVnxG5rlYEn4Rc92M

Text 13: Feldman, D. (2009, August 15). Gypsy couple accused in 'sweetheart scam'. NWCM.com. Retrieved from http://www.nwcn.com/archive/61203312.html

Text 14: Weir, R. (2007, June 8). Keen cop gets jewel of a collar. New York Daily News. Retrieved from http://www.nydailynews.com/news/crime/keen-jewel-collar-article-1.221400

Text 15: Detectives nab phony Water Dept. employee in NE. (2009, September 22). Philly.com. Retrieved from http://www.philly.com/philly/blogs/dncrime/60480822.html

Text 16: Kemp, J. (2010, February 1). Two scammers, who target elderly, looted at least 10 homes in Queens since September. New York Daily News. Retrieved from http://www.nydailynews.com/news/ny crime/2010/02/02/2010-02-02_scammers_who_target_elderly_eyed_in_burglary_string.html 
Text 17: Bernstein-Wax. J. (2010, February 24). Woman arrested for Atherton home burglary. InsideBayArea.com Retrieved from http://www.insidebayarea.com/sanmateocountytimes/localnews/ ci 14466733

Text 18: CPD: Drugged-up woman arrested while begging for money with sick baby. (2011, June 9). Claycord News and Talk. Retrieved from http://claycord.com/2011/06/og/ cpd-drugged-upwoman-arrested-while-begging-for-money-with-sick-baby/

Text 19: Update: Gypsies once again spotted outside main Post Office in Concord. (2011, June 11). Claycord News and Talk. Retrieved from http://claycord.com/2011/06/11/ gypsies-once-againspotted-outside-the-main-post-office-in-concord/

Text 20: Denson, B. (2011, April 25). Portland Gypsy patriarch sentenced to short prison term in tax case. Oregon Live. Retrieved from http://www.oregonlive.com/portland/index.ssf/2011/o4/portland gypsy patriarch sente.html

Text 21: Godfrey, T. (2012, March 10). Roma refugee claimants face 70o charges. Toronto Sun. Retrieved from http://www.torontosun.com/2012/03/10/roma-refugee-claimants-face-70o-charges

Text 22: Godfrey, T. (2011, December 21). 3 women arrested for theft. Toronto Sun. Retrieved from http://www.torontosun.com/2011/12/21/3-women-arrested-for-theft

Text 23: Doucette, C. (2012, October 19). Arrests in distraction thefts targeting Italian women. Toronto Sun. Retrieved from http://www.torontosun.com/2012/10/19/ arrests-in-distractionthefts-targeting-italian-women

\section{Crime reports featuring CEOs}

Text 1: Farzad, R. (2005, June 21). Jail terms for 2 at top of Adelphia. The New York Times. Retrieved from http://www.nytimes.com/2005/o6/21/business/21rigas.html?_r=1

Text 2: Zambito, T. \& Smith, G. (2008, December 13). Feds say Bernard Madoff's \$5o billion Ponzi scheme was worst ever. New York Daily News. Retrieved from http://articles.nydailynews.com/ 2008-12-13/news/17913355_1_bernard-madoff-madoff-securities-ponzi-scheme

Text 3: Efrati, A., Lauricella, T. \& Searcey, D. (2008, December 12). Top broker accused of $\$ 50$ billion fraud. The Wall Street Journal. Retrieved from http://online.wsj.com/article/SB122903010173099377.html

Text 4: Gearty, R.\&Goldiner, D. (2005, March 16). Ebbers guilty inWorldcon. New York Daily News. Retrieved from http://www.nydailynews.com/archives/news/ebbers-guilty-worldcon-article-1.643382

Text 5: White, B. \& Drezen, R. (2005, March 16). WorldCom's Ebbers convicted. The Washington Post. Retrieved from http://www.washingtonpost.com/wp-dyn/articles/A36896-2005Mar15 2.html

Text 6: Gordon, M. (2010, April 17). Goldman Sachs accused of fraud. The Buffalo News. Retrieved from http://www.buffalonews.com/2010/04/16/1021881/goldman-sachs-accused-of-fraud.html

Text 7: Zuckerman, G. Craig, S. \& Ng, Serena. (2010, April 17). Goldman Sachs charged with fraud. The Wall Street Journal. Retrieved from http://online.wsj.com/article/SB1000142405270230349130457518 7920845670844.html?mod=WSJ hpp LEFTTopStories

Text 8: Barrionuevo, A. (2006, May 26). Two Enron chiefs are convicted of fraud and conspiracy trial. The New York Times. Retrieved from http://www.nytimes.com/2006/05/26/business/ businessspecial3/26enron.html

Text 9: Branigan,W. (2004, March 5). Martha Stewart convicted on all counts. The Washington Post. Retrieved from http://www.washingtonpost.com/wp-dyn/articles/A33685-2004Mar5 2.html

Text 10: Kravitz, D. (2011, December 16). CEOs of Fannie Mae, Freddie Mac. The Arizona Republic. Retrieved from http://www.azcentral.com/arizonarepublic/news/articles/2011/12/16/20111216fanniemae-freddie-mac-charges.html

Text 11: Lattman, P. \& Ahmed, A. (2012, January 18). U.S. charges 7 for insider trading of Dell stock. The New York Times (Dealbook). Retrieved from http://dealbook.nytimes. com/2012/o1/18/f-b-imakes-insider-trading-arrests/

Text 12: Bunge, J., Patterson, S. \& Steinberg, J. (2012, July 16). Peregrine's dramatic confession. The Wall Street Journal. Retrieved from http://online.wsj.com/article/SB10001424052702303740704577524873 g09864282.html 